\title{
A living fossil Tetrapus fig wasp (Hymenoptera: Agaoninae) developing in extant Neotropical fig species (Moraceae: Ficus, section Pharmacosycea)
}

\section{William Ramírez-Benavides}

Escuela de Agronomía, Facultad de Ciencias Agroalimentarias, Universidad de Costa Rica, San José, Costa Rica; william.ramirez.benavides@gmail.com

\author{
Received 11-VIII-2015. Corrected 13-V-2016. Accepted 15-VI-2016.
}

\begin{abstract}
It has been assumed that Tetrapus female wasps (Agaonidae s.s.), the pollinators of the figs of the New World, section Pharmacosycea, are mainly characterized by the presence of one mandibular appendange only, and that it is the most ancestral clade of extant Agaonidae s.s., and the males are tetrapodous. The main objective of this work was to study five Tetrapus morphotypes, whose females have two mandibular appendages and the males are hexapodous, their fig host association and phylogenetic position to the family Agaonidae. The question of which group of fig pollinating wasps and associated figs are the sister to the rest of the pollinating agaonids, and figs respectively remain open. I report a group of New World extant Tetrapus morphotypes (Agaonidae: Agaoninae) provisionally assigned to Hexapus subg. nov. in preparation. Currently, Tetrapus appears as the sister taxon to all other fig pollinating taxa. Howeveer, morphologically, ecologically, geographically and historically Hexapus seems to be the ancestral clade of the extant Agaoninae. Hexapus morphotypes develop in fig species of subsection Petenenses (section Pharmacosycea). In the known extant Tetrapus, the females have one mandibular appendage and the males have reduced one or two short-lobe atrophied non-functional midlegs (tetrapodous). Hexapus females have two free mandibular appendages, and the males have five segmented functional mid-legs (hexapodous). Molecularly Hexapus seems to be the ancestral clade of extant Agaoninae; e.g., a Tetrapus sp. of Ficus crassivenosa was placed by other author as the ancestral clade of 101 wasp species, representing 19 worldwide Agaoninae genera, including four Tetrapus species. In Tetrapus sp. of Ficus crassivenosa, the female has two mandibular appendages and the male is hexapodous. The females of T. apopnus and T. delclosi, preserved in Early to mid-Miocene amber from the Dominican Republic, also have two mandibular appendages and the general morphology of extant Hexapus. I suggest that Hexapus stands up as a living fossil and the sister clade of Tetrapus s.s. The presence of extant Hexapus; as well as extant Tetrapus and their fig host species, especially in South America supports a Southern Gondwanaland origin for both of them, but not a trans-Pacific migrating connection with tropical America for section Pharmacosycea (the host of Tetrapus and Hexapus), a long oceanic dispersal, high levels of stem extinction of Tetrapus or Atlantic land connections, as proposed by other authors. However, lastly it has been assumed that figs and their pollinators arose simultaneously in Eurasia during early Tertiary and spread southwards from it. Most of the morphological and molecular studies of the fig biology of Agaoninae and Ficus, did not include Hexapus morphotypes and their fig hosts, and assumed that Tetrapus is the most ancestral clade of the extant fig pollinating wasps. Rev. Biol. Trop. 64 (4): 1721-1735. Epub 2016 December 01.
\end{abstract}

Key words: Agaoninae, Tetrapus, Hexapus, Ficus, section Pharmacosycea, subsection Petenenses, living fossil wasps.

Ficus is a Pantropical group that comprises about 735 species worldwide (Berg \& Corner, 2005). It is found in all regions where frost does not occur (Corner, 1958), especially in areas of the Southern Hemisphere, including very small isolated oceanic islands (McKey, 1989; Yokoyama, 2003; Azuma, Harrison, Nakamura, \& Su, 2010; Ramírez, Gómez, Salazar, \& Aguilar, 2011). New World Ficus has two endemic sections: Pharmacosycea (Miq.) 
Benth. \& Hook. f. subgenus Pharmacosycea (Miq.) Miq., pollinated by Tetrapus Mayr; and section Americana Miq. subgenus Urostigma (Gasp.) Miq., pollinated by Pegoscapus Cameron. Section Pharmacosycea is a relatively small group (Berg, 1989), comprising at least 25 species (Berg, 2009), of which 19 are found in Ecuador. Ficus is characterized by its unique flask-like urceolate inflorescence (fig or syconium) with internal staminate and pistillate flowers and a small circular or split-shaped terminal orifice, the ostiolum, barred by stiff bracts, through which the symbiotic pollinating wasps must pass to reach the syconial cavity, oviposit in some of the female florets that become galls, where their larvae develop, and pollinate some of them that become seeds. Dispersal of Ficus is a double problem, since the pollinators must accompany the host plant (Corner, 1958). Furthermore, Ficus pollen grains are very small (7-22 $\mu \mathrm{m})$, ellipsoid or oblate, with smooth exine (Berg \& Corner, 2005) and probably lack the vacuolated stage (Ramírez, 2007); consequently, they must suffer fast dehydration and death during long distant transportation or emigration journeys (Ramírez, 1989; 2007). Furthermore, fig seeds are small, 0.5-5 mm long (Corner, 1958), short-lived, and the seedlings initially grow very slowly (Ramírez pers. obs.). New World section Pharmacosycea has free standing leptocaulous terrestrial trees, although Ficus crassiuscula Standl. (a host of an Hexapus morphotype) is usually hemi-epiphytic (Berg, 2009). According to Berg and Corner (2005), events of long-distance in Ficus dispersal will probably rarely result in reproduction and establishment by absence of pollinators, and population of trees to allow establishment of the pollinators as well. However, Cruaud et al. (2011) proposed fruit pigeons, in part, for long distance trans-oceanic dispersal for fig fruits. Ecologically, Ficus provides one of the most important continuous food resources year around, e.g., Harrison (2005) noted that over 1200 vertebrate species feed on figs. Furthermore, the eclosing new generation of female wasps is eagerly consumed by ants, flying swallows and Anisoptera dragon flies; while the wingless males are consumed by ants and staphylinid beetles. Furthermore, the dead foundresses are internally consumed by Parasitodiplogaster nematodes (Ramírez \& Salazar, 2015). It has been suggested that the mutual relationship between Ficus and the pollinating Agaoninae was probably established before the break of Gondwana (Weiblen, 2002); while Berg and Corner (2005) noted that the general pattern of distribution and diversification suggest that the genus Ficus originated in Eastern Gondwana. Interestingly, Corner (1967) noted that subgenus Pharmacosycea seems to connect with an even earlier stock of Ficus.

\section{Subgenus Pharmacosycea and its pol-} linators: Subgenus Pharmacosycea is monoecious with two sections (Berg \& Corner, 2005): Pharmacosycea (Miq.) Benth \& Hook. f. and Oreosycea Corner (Berg \& Corner, 2005); both sections are pollinated by different Agaoninae genera: Pharmacosycea, by Tetrapus (Mayr, 1885), which is a passive pollinator; Oreosycea, by Dolichoris (Wiebes, 1979), which is an active pollinator, with the exception of one species (Wiebes, 1979). New World Section Pharmacosycea has ca. 25 species; while Oreosycea, ca. 45, ranging from Africa and Madagascar to Fiji and New Caledonia (Berg \& Corner, 2005). Section Pharmacosycea has two subsections: Bergianae and Petenenses (Berg, 2006). Tetrapus, as well as most other pollinating Agaoninae, are usually tiny (no more than $3 \mathrm{~mm}$ in length), usually dark colored, diurnal, poor flyers, and do not feed as adults (Ramírez, Monge, \& Chavarría, 2009, and references therein).

The pollinators of section Pharmacosycea: Currently, Tetrapus has been assumed to be the exclusive passive pollinator of section Pharmacosycea (Corner, 1960; Ramírez, 1970; Bouček, 1993; Ramírez, 1994; Wiebes, 1995). Ramírez (1978; 1991) considered that Tetrapus seemed to be composed of two well defined groups: in one group (Tetrapus), the females have one mandibular appendage and the males are tetrapodous; in the other, the females have 
two mandibular appendages and the males are hexapodous. Bouček (1993) referred about three Tetrapus with the female mandible split from the apex; while Wiebes (1995), mentioned two saw-like appendages.

Geographical origin and dispersal of subgenus Pharmacosycea and Tetrapus: Corner (1967) suggested that subgenus Pharmacosycea originated in the region that connected the Solomon Islands, New Hebrides and New Caledonia, it traveled via Caledonia to Asia, but very early a detachment went to America. He also noted that subgenus Pharmacosycea clearly has a trans-Pacific history that was not of small islands, but of high forest and that North America could not have been the source supply of Pharmacosycea to South America. Rønsted et al. (2005) noted that, if their age estimates are correct, this could imply that long distance oceanic dispersal is an important process in the present distribution of Ficus as also noted by Datwiler and Weiblen (2004); and that, the South American section Pharmacosycea would have separated from the rest of Ficus only 60 Myr ago, which postdates the separation of South America from Africa (about 90-100 Myr ago) during the break-up of Gondwana. Lopez-Vaamononde et al. (2009) noted that if their estimates and ancestral areas are correct reconstructions, it would imply that the current presence of Tetrapus and its associated Pharmacosycea figs in South America could be the result of long distance oceanic dispersal from Asia to the Neotropics; and that alternatively, high levels of stem lineage extinction could explain the observed young age for extant species of Tetrapus and section Pharmacosycea. Cruaud et al. (2012) estimated 74.9 Ma for the stem Pharmacosycea/Tetrapus, and that, biogeographic analyses indicated that the present-day distribution of fig and pollinator lineages, is consistent with a Eurasian origin and subsequent dispersal, rather than with Gondwanan vicariance. Furthermore, Cruaud et al. (2012) concluded that neither their study nor previous ones have strong basis for inferring which group was sister to all other agaonids.

Time evolution of the Ficus-Agaoninae association with special reference to section Pharmacosycea and Tetrapus: The age, geographical origin and major periods of diversion of Ficus remain controversial (LopezVaamonde et al., 2009). For the geographical origin of the association of Ficus-Agaonidae, it has been suggested that the pollinating wasps evolved during the Cretaceous period (Corner, 1958) in the Southern Hemisphere (Gondwanaland) (Murray, 1985). According to Machado, Jousselin, Kjellberg, Compton and Herre (2001), Ficus and its pollinating wasps seem to be of late Cretaceous origin. Ramírez (1978, Fig. 21; 1991, Fig. 18), in his morphological cladistic analyses about the evolution of the mandibular appendage, and the pollinating syndromes of the Agaoninae, placed Tetrapus as the most basal clade to all other extant Agaoninae groups, and section Pharmacosycea, as the most ancestral group of Ficus. Those cladistic positions were corroborated by molecular phylogenetic analyses by Herre et al. (1996), Weiblen (2000), Rønsted et al. (2005), Rønsted, Weiblen, Clement, Zerega and Savolainen (2008), and Munro et al. (2011). Machado et al. (2001) noted that the passively pollinating Tetrapus appears to be the most ancient pollinator genus associated with the monoecious Neotropical subgenus Pharmacosycea; and that, both morphological and molecular data, support New World section Pharmacosycea as the earliest derivation among existing figs. Furthermore, Machado, Herre, McCafferty and Bermingham (1996) noted that the ancestors of Neotropical Pharmacosycea and Tetrapus probably arose at the origin of their mutualism ca. 90 Myr ago in Gondwana. Rønsted et al. (2005) supported that section Pharmacosycea is the oldest group of Ficus. Lopez-Vaamonde et al. (2009) also confirmed that Tetrapus was consistently placed as a sister group of the rest of the extant pollinating fig wasps. Furthemore, Rønsted et al. (2005) obtained confidence intervals of 98-105 Myr for the age of the root 
node of Ficus, and 66-101 Myr for the age of the root node of the wasps. While Lopez-Vaamonde et al. (2009) estimated that the crown group of Agaonidae could have originated any time between 54 and $216 \mathrm{Myr}$ ago. However, Zerega, Clement, Datwyler and Weiblen (2005) suggested that the figs may have radiated more recently after the break-up of Gondwana, and gave a range of 40-51 Myr for the crown group age of Ficus. Furthermore, Zerega et al. (2005) results do not support the hypothesis of simultaneous diversification between figs and fig wasps and suggested that figs may have radiated more recently, during the Tertiary ( $c f$. Cruaud et al. (2012) for codiversification of figs and fig-pollinating wasps). However, the Tetrapus species molecularly analyzed by those authors, as well as others, correspond to extant Tetrapus (Herre et al., 1996; Machado et al., 1996; 2001; Jousselin, Rasplus, \& Kjellberg, 2003; Datwyler \& Weiblen, 2004; Rønsted et al., 2005; 2008; Jian, Zhu, \& Zhen, 2006; Lopez-Vaamonde et al., 2009; Azuma et al., 2010; Erasmus, van Noort, Jousselin, \& Greeff, 2010; Munro et al., 2011; Cruad et al., 2009, 2011, 2012). The objectives of this work were to study the association of five Tetrapus morphotypes whose females have two independent mandibular appendages and hexapodous males; explain their origin and morphological relationships to other pollinating wasps of subgenus Pharmacosycea and other pollinating genera, their taxonomic position, and its origin.

\section{MATERIALS AND METHODS}

Syconia of F. crassiuscula Standl. were collected in Santa Cruz, Turrialba, Costa Rica $\left(09^{\circ} 58^{\prime} 02^{\prime \prime} \mathrm{N}-83^{\circ} 44^{\prime} 15^{\prime \prime} \mathrm{W}\right.$, at $1430 \mathrm{~m}$ of elevation), from F. macbridei Standl. in Tapantí National Park, Costa Rica (09 46'13.2" N $83^{\circ} 47^{\prime} 59^{\prime \prime} \mathrm{W}$, at $1239 \mathrm{~m}$ in elevation) and of F. crassivenosa W. Burger, from near Quebrada Cataratitas, San Ramón, Alajuela, Costa Rica $\left(10^{\circ} 14^{\prime} 3.26^{\prime \prime} \mathrm{N}-84^{\circ} 31^{\prime} 29.39^{\prime \prime} \mathrm{W}\right.$, at 755 $\mathrm{m}$ in elevation). Naturally colonized syconia of Ficus crassiuscula and of F. macbridei were collected one day before they reached the male phase. Each syconium was individually enclosed in a tightly capped jar. Once the wasps emerged from the syconia, they were put to sleep with acetone and preserved in ethanol $70 \%$ for further identification and dissection. Hexapus females and males were also collected by the author from the syconia of a cauliflorous riparian Pharmacosycea sp. in Jiménez, Biscucuy, Portuguesa State, Venezuela in 1966. The pollinators of $F$. petenensis Lundell was collected from Veracruz, Mexico, and described as Hexapus ramirezi by Xochitl M. Cuevas-Figueroa (2009, unpublished). A female of $H$. ramirezi was obtained from a preserved syconium of $F$. petenensis Lundell $(=F$. apollinaris Dugand); voucher number 2502 deposited at INBio Herbarium, Santo Domingo de Heredia, Costa Rica. The illustrations of two fossil female Hexapus are used with the permission of Enrique Peñalver (2006, Fig. 2a y Fig. 2b). The dissections of the wasps were made with the help of a dissecting microscope while the wasps were submerged in $70 \%$ ethanol in a Syracuse container, the body structures were dislodged by mean of minute Nadel hook and mounted in Hoyer's fluid to be illustrated.

The species of Ficus studied were identified by the author using the descriptions of Burger (1977) and Berg (2009). The scientific names of the figs were consulted in Tropicos ${ }^{\circledR}$ of the Missouri Botanical Garden and in Berg (2009). The term Agaoninae corresponds to the pollinating wasps, sensu Bouček (1988) or to Agaonidae sensu Rasplus, Kerdelhué, Le Clainche and Mondor (1998). The term Tetrapus refers to Tetrapus Mayr (1885), and Hexapus to a Tetrapus group, who's female have two independent mandibular appendages and hexapodous males, noted as Hexapus subg. nov. in preparation. Since the five morphotypes of Hexapus studied were collected from five defined Ficus spp. and from different geographical areas, they are assumed to be distinct morphotypes until they are definitely described. The mandibles of Nigeriella excavata were also studied. 


\section{RESULTS}

Females of the five Hexapus morphotypes studied had two free mandibular appendages (Fig. 1) and males with functional mid legs (hexapodous). They were the passive pollinators of five New World fig species of section Pharmacosycea, subsection Petenenses. The females are further characterized by an elongate head with a gular bridge without a sclerotized median carina or a felted line, mandibles with one gland only, absence of labrum, bilobed clypeus with a median setose carina, pedicel without axial spines, third segment with three completely fused anelli and a short unsegmented acuminated projection, labiomaxillary complex with distinct stipes and galea, bacilliform process pointing backward, segmented labium, forewing closed costal cell, spurious veins and moderate pilosity, and a twelfth flagellomere.

The males have two mandibular glands and antennae basically 4-segmented with an anellus, while the female has one gland

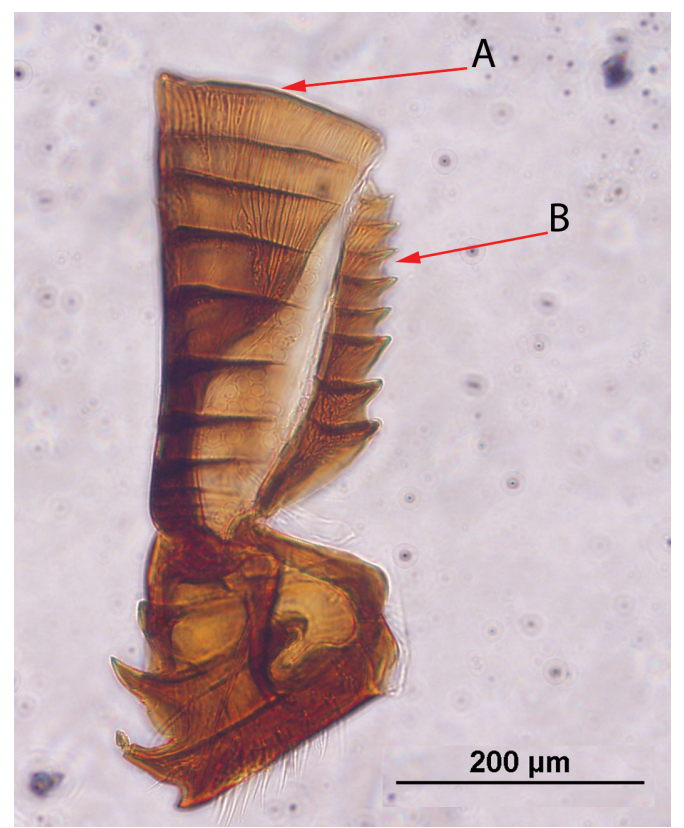

Fig. 1. Female mandible of Hexapus morphotype, pollinator of Ficus macbridei. A. External appendage. B. Internal appendage. and do not break off the antennae and wings when they penetrate through the ostiolum (Ramírez, 1970).

Tetrapus females have one mandibular appendage only (Fig. 2), while Nigeriella excavata, the pollinator of the African Ficus tettensis (Section Malvanthera) has one mandibular appendage, with two elongate lateral sclerotized median membranous areas (Fig. 3). Two fossil Tetrapus (T. apopnus and $T$. delclosi), described by Peñalver, Engel and Grimaldi (2006) preserved in early Miocene amber from the Dominican Republic, also have

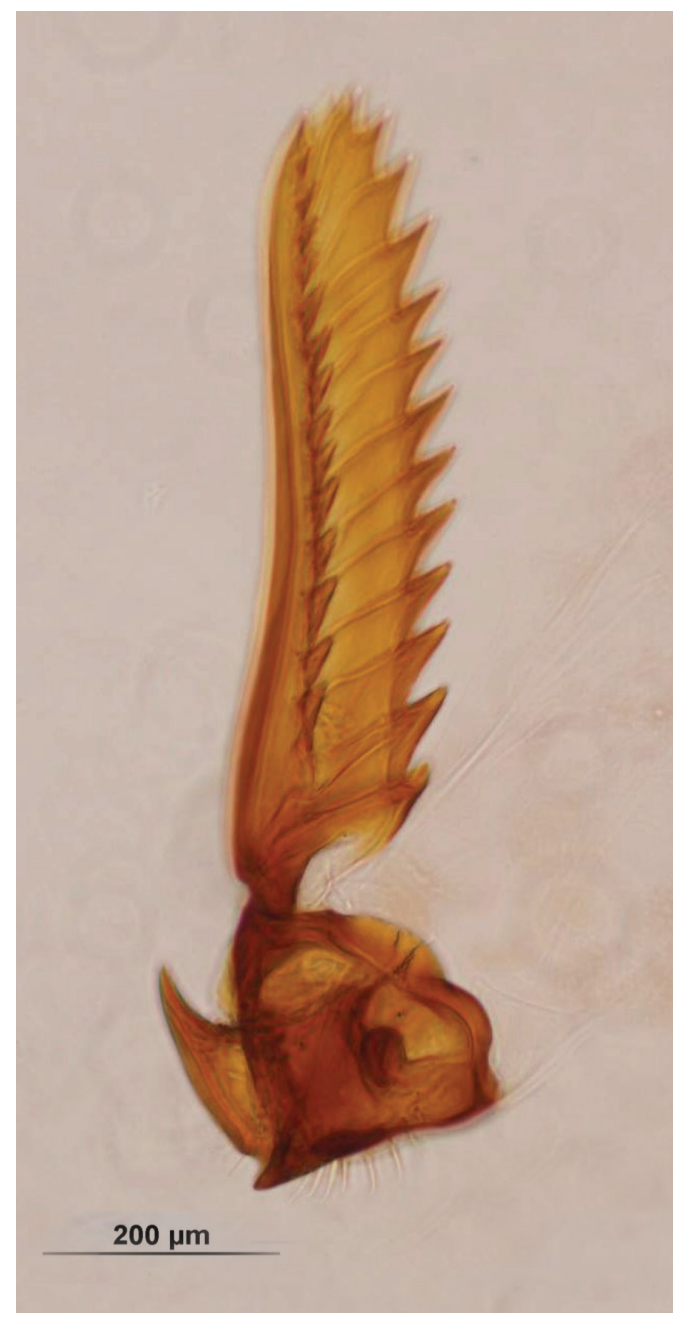

Fig. 2. Female mandible of Tetrapus morphotype, pollinator of Ficus glabrata. a. Mandibular appendage. 


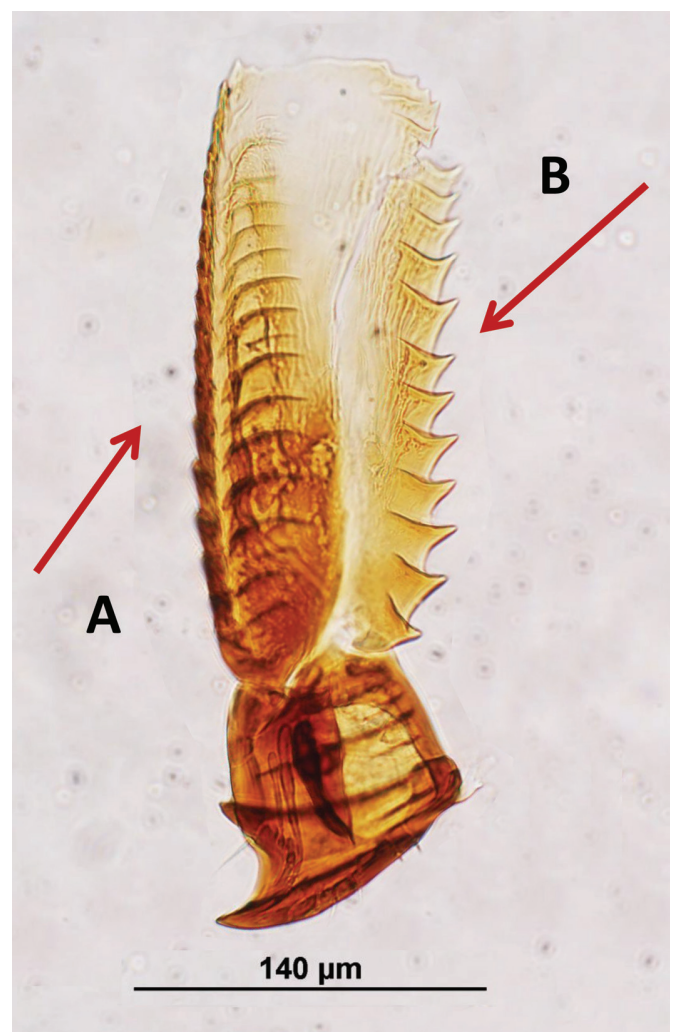

Fig. 3. Mandible of Nigeriella excavata, pollinator of Ficus tettensis (section Malvanthera). A. External sclerotized section. B. Internal sclerotized section.

two mandibular appendages (Fig. 4), and the general morphology of extant morphotypes of Hexapus. The ostiollum of Ficus crassiuscula (Fig. 5); as well as, all other fig species pollinated by Hexapus, is constituted by a group of few external imbricated bracts (Fig. 5a), followed by inflexed bract, forming a tubular entrance (Fig 5b). There was a relationship between the presence of two mandibular appendages of extant female morphotype of Hexapus and the ostiolar conformation of the five hosting fig species studied. Hexapus is mainly associated with subsection Petenenses fig species

Fig. 4. Two fossil Tetrapus females preserved in Early Mioene (Burdigaliam) amber from Dominican Republic, after Peñalver et al. (2006). A. T. delclosi. B. T. apopnus. A. Internal appendage. b. External appendage.

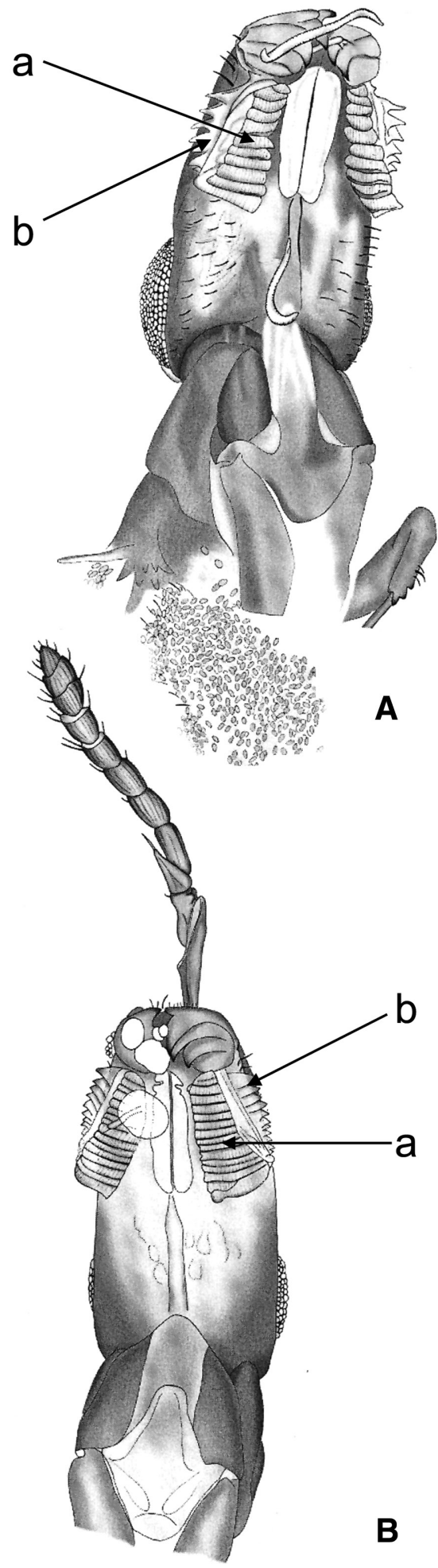

B 


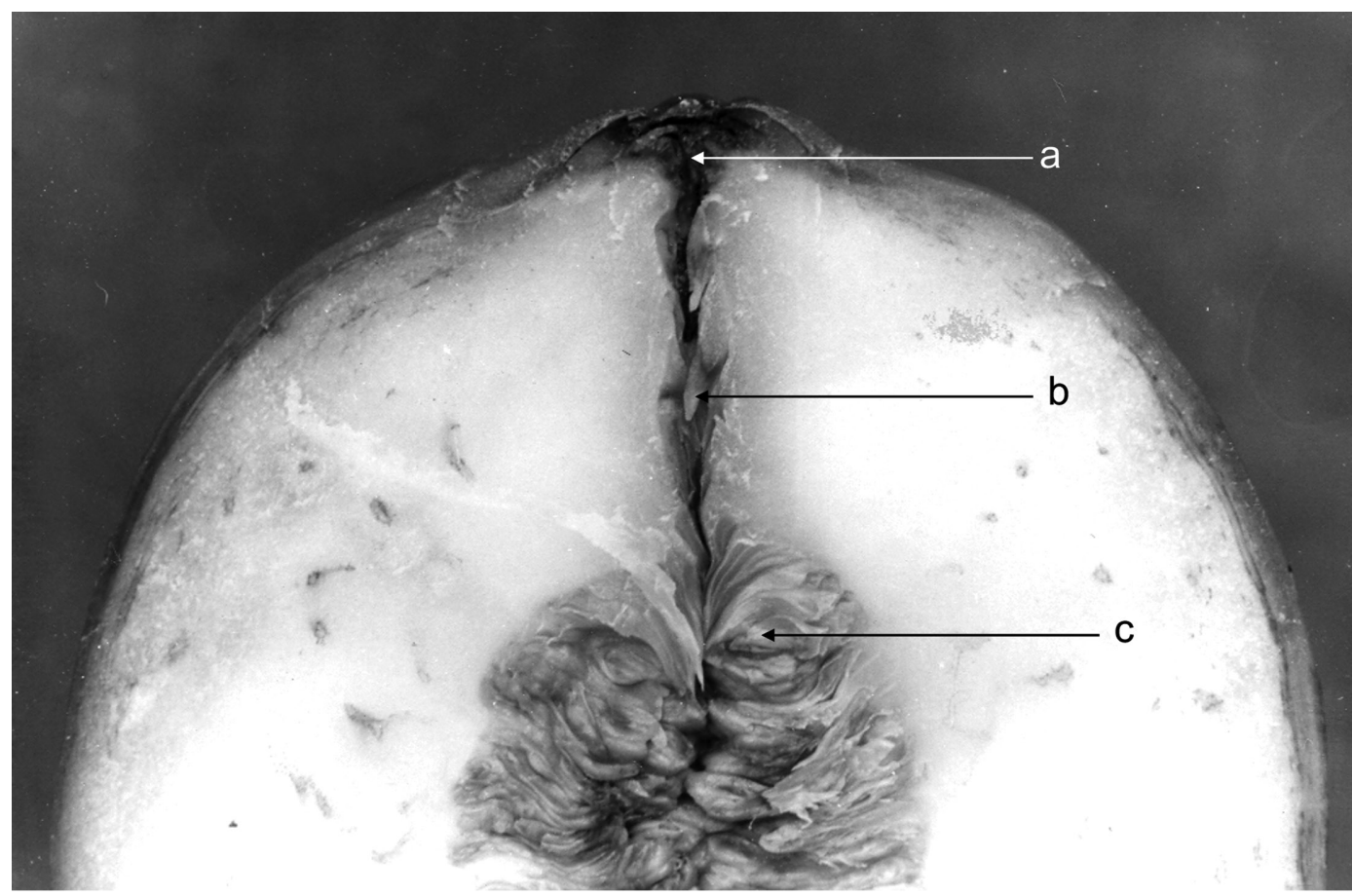

Fig. 5. Ostiolum of Ficus crassiuscula. a Helicoidal entrance. b. Linear entrance. c. Gall flower.

that predominate in submontane humid forests up to $2900 \mathrm{~m}$ in altitude, or more; as described by Berg (2009). Due to the conformation of the ostiolum and to the distribution of the fig species in submontane, described by Berg (2009), and montane humid forest from 900 to $2900 \mathrm{~m}$ in altitude or more, the author suggest that at least 10 fig species host Hexapus morphotypes, described by Berg (2009); among them: Ficus bombuscaroana C.C. Berg; F. carchiana C.C. Berg; F. dulciaria Dugand; F. ecuadorensis C.C. Berg; F. gigantosyce Dugand; F. lacunata T.A. Kvitvik; F. loxensis C.C. Berg; F. mutisii Dugand; F. piresiana Vásq. Avila \& C.C. Berg; F. quijosana C.C. Berg. Furthermore, Ficus crassiuscula Standl., F. crassivenosa Burger, F. macbridei Standl., F. petenensis Lundell $(=F$. apollinaris Lundell); (Xochil Cuevas-Figueroa ined.), F. pulchella Schott (Vásquez-Avila pers. com.), and a Venezuelan Pharmacosycea cauliflorous species are known to host Hexapus female morphotypes, and differ from Tetrapus females by having the scape with a sharp lateral subtriangular flange (Fig. 6), instead of a bulging flange (Fig. 7), and because they have a close costal cell (Fig. 8), instead of an open costal cell

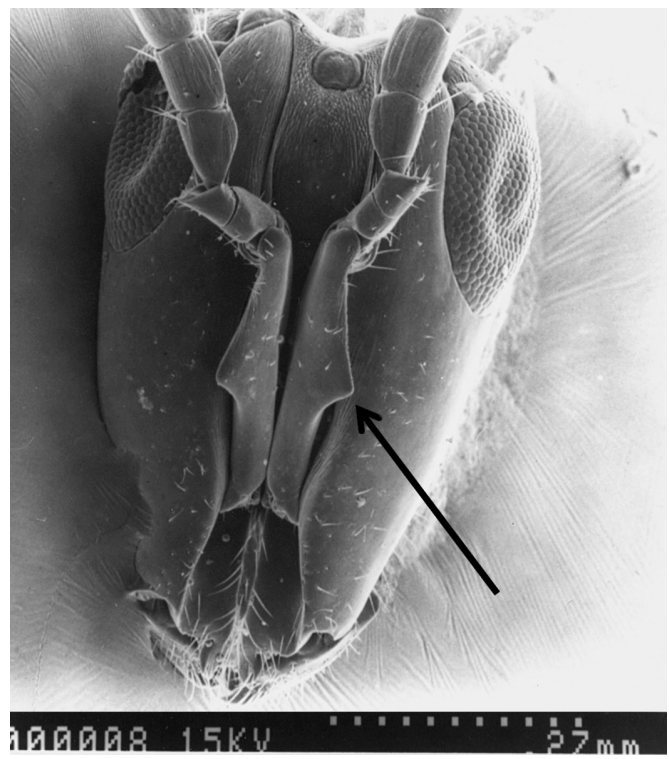

Fig. 6. Head frontal view of Hexapus antennal subtriangular flange (arrow). 


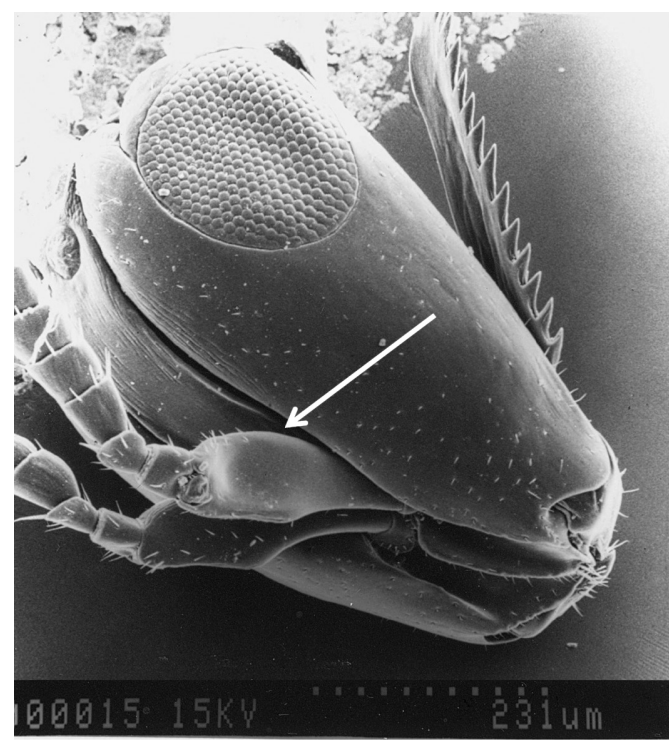

Fig. 7. Head frontal view of Tetrapus morphotype, antennal bulging flange (arrow).
(Fig. 9) and radiating veins, as illustrated by Peñalver et al. (2006, Fig. 4) for T. apopnus. By the contrary, Tetrapus females have open costal cell (Fig. 9). Furthermore, Hexapus females have elongate maxilla (Fig. 10), while Tetrapus have a short heart-shaped maxilla (Fig. 11). Pollen grains of section Pharmacosycea are cylindrical with obtuse ends (Fig. 12). All the Hexapus morphotypes were associated with fig species of subsection Petenenses and Bergianae of New World section Pharmacosycea, subgenus Pharmacosycea.

\section{DISCUSSION}

Hexapus subg. nov. ined., in preparation, belongs to Tetrapus Mayr which has five extant nominal species (Wiebes, 1995). The five Hexapus morphotypes studied are the specific

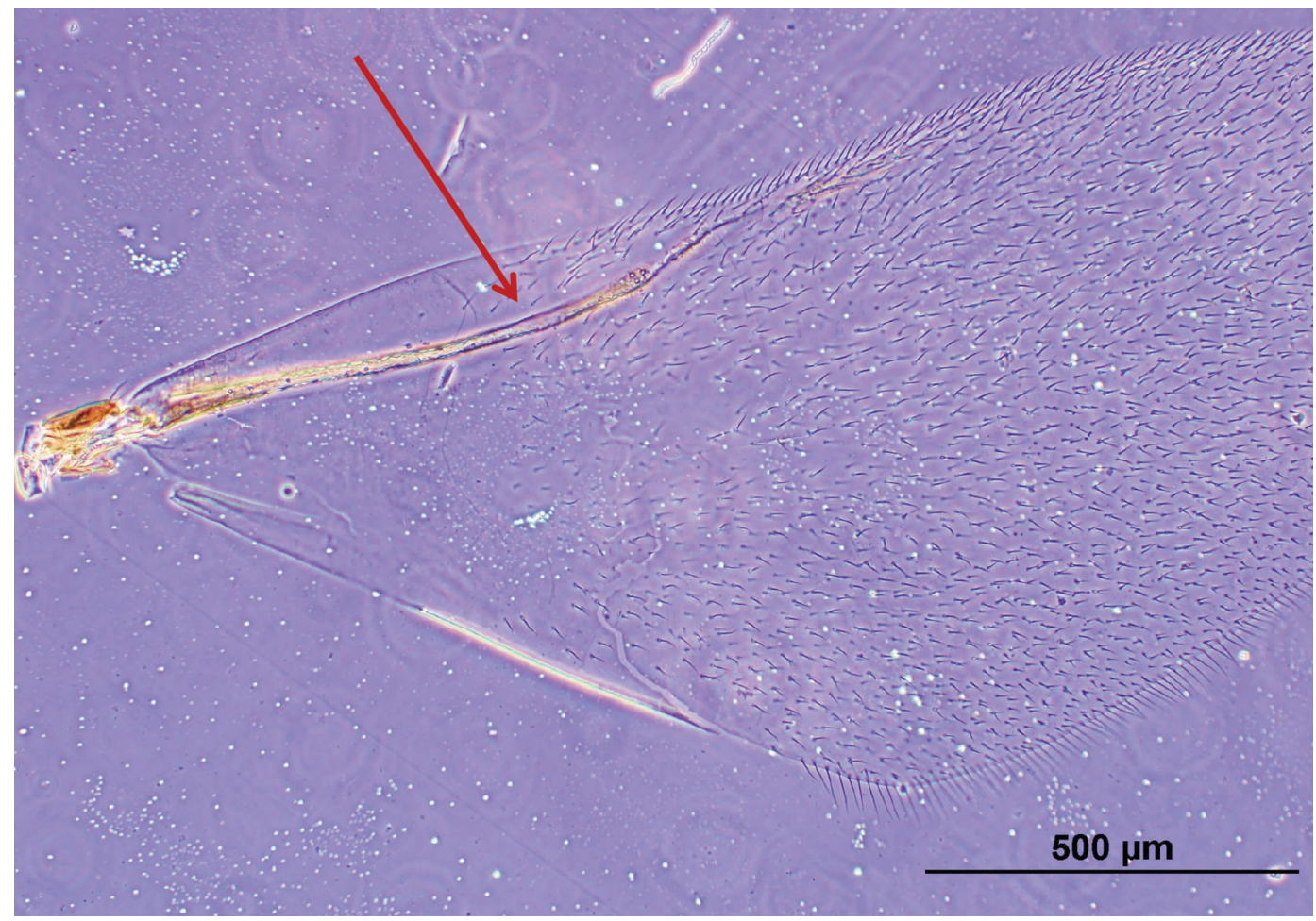

Fig. 8. Forewing basal section of Hexapus morphotype with close costal cell (arrow). 


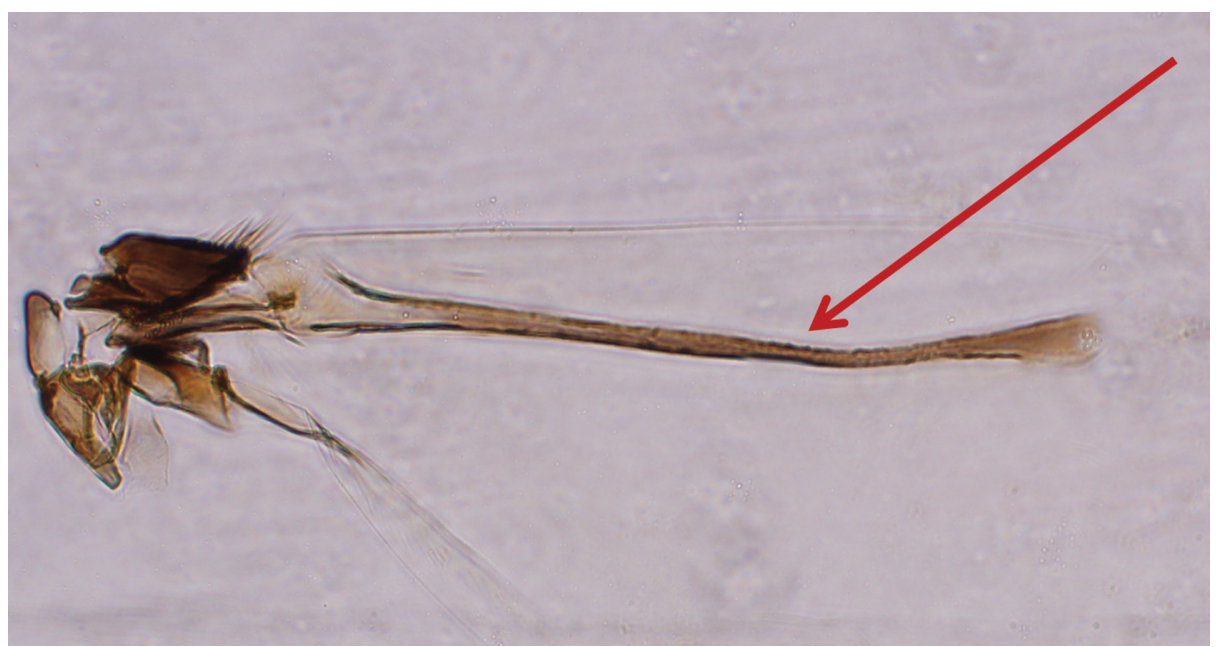

Fig. 9. Forewing basal section of Tetrapus morphotype with close open costal cell.

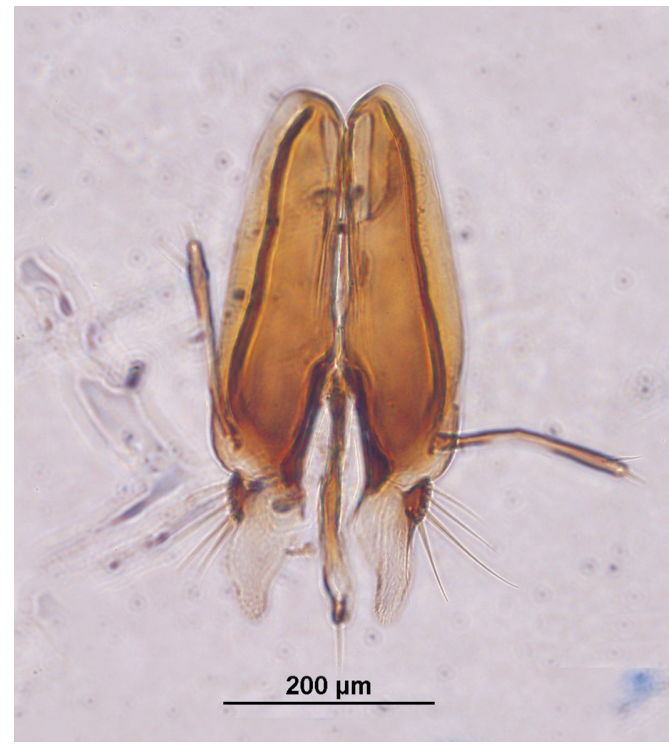

Fig. 10. Labiomaxillary complex of Hexapus morphotype.

pollinators of five species of section Pharmacosycea: subsection Petenenses. Two fossil female Tetrapus (T. apopnus and T. delclosi), described by Peñalver et al. (2006), like those of the extant Hexapus, also have two mandibular appendages, forewing closed costal cell, and most of the general morphology (Peñalver et al., 2006). The ostiola of fig species associated with extant Hexapus morphotypes, have

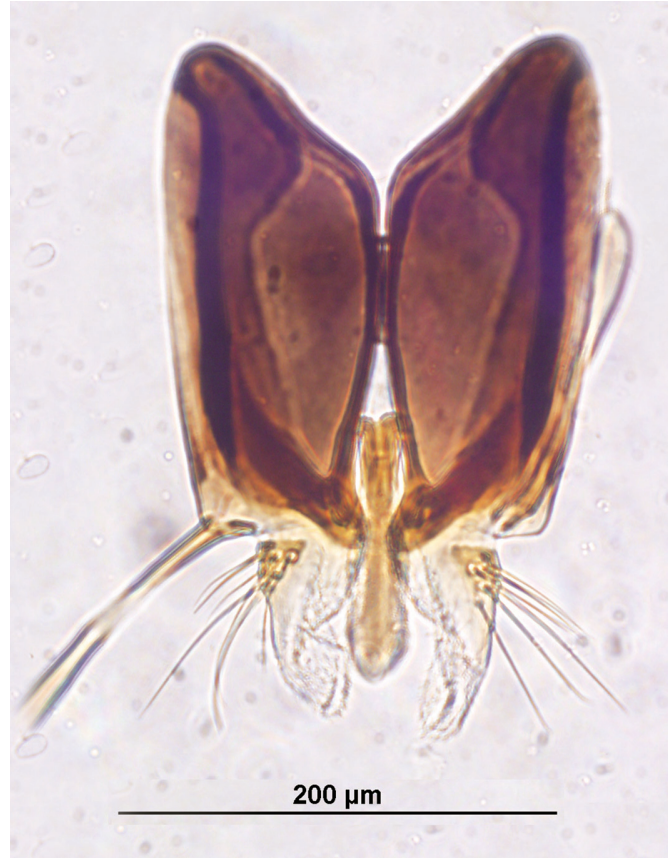

Fig. 11. Labiomaxillary complex of Tetrapus morphotype.

an entrance morphology not found in other fig groups, and are usually protracted at the bottom of a cavity in the apex of the syconium (Berg, 2009); they have several layers of superficial interlocking horizontal appressed bracts; (spiral entrance), followed by a series of inflexed 


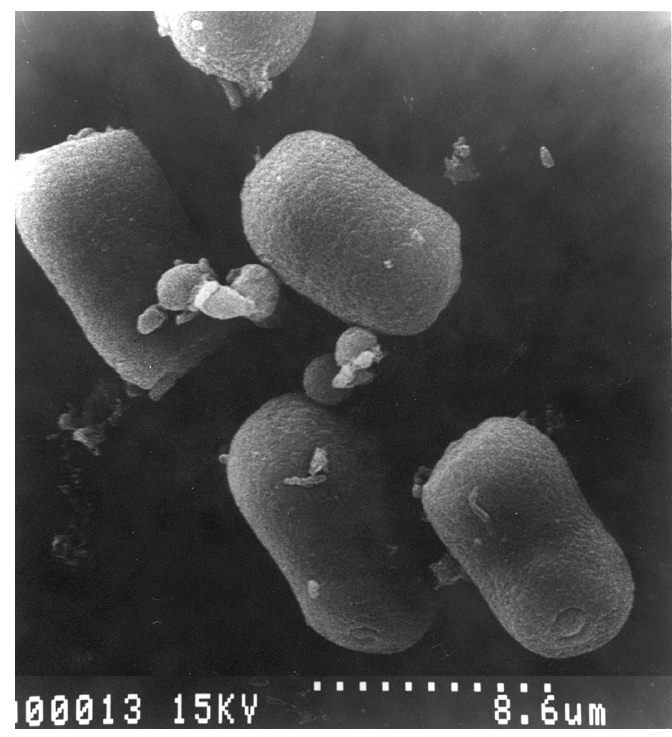

Fig. 12. Pollen grains of Ficus glabrata.

bracts pointing inwards into the syconial cavity; (linear entrance). On the contrary, fig species associated with Tetrapus usually have the ostiolum without distinct superficial interlocking bracts, but a linear tubular entrance only, and the female Tetrapus has one mandibular appendage. All other Agaoninae pollinators have one mandibular appendage. In Hexapus the internal appendage is wide, sub-rectangular, larger than the external one, and provided with lamellae, as in other female agaonines that enter syconia with a spiral ostiole; while the external appendage is narrower, with short lamellae ending in lateral teeth as in Tetrapus. The fossil females of Tetrapus apopnus and $T$. delclosi differ from extant Hexapus because they have an elongate sharp scale-like antennal process in the first flagellomere with an apical long spine, as depicted by Peñalver et al. (2006), which seems to be a Blastophaginae character sensu Wiebes (1982). Both Tetrapus and Hexapus are exclusively cleptoparasited by New World Critogaster Mayr (Sycoryctinae) (Segar, Lopez-Vaamonde, Rasplus, \& Cook, 2012). Hexapus, as well as Tetrapus, are the exclusive pollinators of the New World section Pharmacosycea. Fossilized and extant Hexapus females are uniquely characterized among most extant pollinating Agaoninae groups (taxa) because they have two independent mandibular appendages as depicted by Peñalver et al. (2006) for Tetrapus delclosi and T. apopnus in Early to mid-Miocene., ca. 20-17 Ma (Iturralde-Vinent \& MacPhee, 1996).

Extant Hexapus morphotypes seem to represent the most ancestral pollinating agaonines of Ficus, because among other pleisiomorphic characters: 1- the females do not possess a gular bridge composed of carinated sclerite, as assumed by Rasplus et al. (1988) for Agaoninae; 2- the antenna has a terminal bottom (terminal nipple), as found in Pteromalidae (Grahan, 1969), which is considered as a separate $12^{\text {th }}$ flageromere, homologous to the apical segment of Rotoitidae, and also reported for some Eucharidae (Heraty et al., 2013 and references there in). Furthermore, the female Hexapus is uniquely characterized among other Agaoninae by the possession of two independent mandibular appendages. Due to the fact that Tetrapus and Hexapus morphotypes are passive pollinators (Ramírez, 1978), as well as to their ecology, the author considers that both groups are more ancestral than the fossilized 'Ponera' minuta, described by Compton et al. (2010), and Pegoscapus peritus described by Peñalver et al. (2006), because both species had a general Blastophaginae morphology, sensu Wiebes (1982), and possessed pollen pockets which are associated with active pollination (Ramírez, 1978; Kjellberg et al., 2001; Cook, Bean, Power, \& Dixon, 2004). Compton et al. (2010) noted that the pollen grains found in the pollen pockets of 'Ponera' minuta were psilate and oblate as those found in other modern Ficus species; and that, ' $P$ '. minuta was an active pollinator and the host tree had dioecious breeding system. By the contrary, section Pharmacosycea pollen grains are cylindrical with obtuse ends, regulate and with a median constriction; as also illustrated by Ramírez and Malavasi (1997), for pollen grains carried by Pleistodontes plebejus (Wiebes), a passive pollinator of Ficus hesperidiiformis King, of section Malvanthera (Cook et al., 
2004). According to Wang, Chen, Li, Zhang and Yang (2014) cylindrical and spherical pollen with obtuse end is only found in passively pollinated figs.

The extinct and extant Hexapus seem to be the sister clade of extant Tetrapus, the most ancestral clade of other extant Agaoninae and to represent a living fossil. It is hypothesized that the association, section Pharmacosycea, subsection Petenenses evolved in the Southern Hemisphere as assumed by Murray (1985) for Agaoninae, before the Gondwanan break (Weiblen, 2002) and that the Agaoninae ancestor could had been a Hexapus-like wasp; other way, the author hypothesizes that there had been an unknown ancestral Agaoninae-Ficus association, that originated in Eastern Gondwana, in agreement with Berg and Corner (2005); and that subgenus Pharmacosycea connects with an even earlier stock of Ficus, and suggested by Corner (1967). On the contrary, Cruad et al. (2012) stated that their ancestral recognition, suggests that figs, and their pollinators, arose simultaneously in Eurasia and the major lineages of figs, and pollinators, split during the Tertiary; and it appears that, posteriorly, they spread Southward from Eurasia. Furthermore, they noted that their, biogeography analyses indicate that Pharmacosycea and Tetrapus diverged before South America split from Antarctica (74.9-62.1 My); and that both lineages might have reached America across North Atlantic bridges ( $c f$. Corner, 1967; Datwyler \& Weiblen, 2004).

It is hypothesized that the ancestral Agaoninae that gave origin to Hexapus or their ancestors, also had two mandibular appendages, as seem to be still found as remnants, in some extant Old World pollinating agaonines e.g., Eupristina (E.) grassi Grandi (1916), and Saunders (1883) for E. masoni (Saunders); furthermore, E. (P.) koninsbergi Grandi, also seems to has two mandibular appendages, as illustrated by Chen and Chou (1997). Nigeriella excavata Compton (an African species) have a wide elongate mandibular appendage, with two lateral long sclerotized areas, each section provided with lamellae and denticles separated by a medial membranous area; the two sclerotized mandibular areas of $N$. excavata, may be remnants of two mandibular appendages that became fused. Some Pleistodontes females, e.g. P. nitens and P. schizodontus of Australia, as described and illustrated by LopezVaamonde, Dixon, Cook and Rasplus (2002, Fig. 21 and Fig. 44), also have a mandibular appendage that recalls the presence of two fused appendages. All other described Agaoninae females have one mandibular appendage.

It is suggested that the ancestral fig ostiolum had a superficial layer with superficial interlocking bracts followed by an internal linear passage as found in subsection Petenenses (cf. Jousselin et al., 2003). The mandibular appendages of Hexapus and Tetrapus females, coevolved in response to the different ostiolar morphology of the two Pharmacosycea subsections (Petenenses and Bergianae). In Hexapus the lamellate internal appendage is used to displace the female through the superficial spiral ostiolar passage; while the external toothed appendage, is used to displace it through the internal linear passage. On the contrary, Tetrapus has one mandibular appendage associated with the ostiolar linear passage of subsection Bergianae. It is suggested that section Pharmacosycea and its pollinators may have evolved in submontane or montane humid tropical forest. By the way, most fig species associated with Hexapus are found from Southern Mexico to Ecuador, especially in humid submontane or montane forest up to $3200 \mathrm{~m}$ or more. Berg (2009) noted that Ecuador gives the impression to be a "melting pot" of section Pharmacosycea species; e.g., out the 25 species, 19 are found in Ecuador; furthermore, out of them, 10 have an ostiolar morphology that suggests their association with Hexapus morphotypes (pers. obs.). Based on the morphological, ecological characters and geographical distribution of extant Hexapus and its fig hosts; the author thinks that this group could be the earliest divergent lineage of extant fig pollinating groups. The probable early association of Hexapus-section Pharmacosycea in Gondwana, or even an earlier stock 
of Ficus that connected with subgenus Pharmacosycea, as suggested by Corner (1967), calls into question the ideas of a trans-Pacific fig route connection (Corner, 1967), North Atlantic land bridges (Cruaud et al., 2012) or long distance trans-oceanic dispersal, proposed for the association Tetrapus- Pharmacosycea in the New World (cf. Corner, 1967; Rønsted et al., 2005; Lopez-Vaamonde et al., 2009; Azuma et al., 2010; Cruaud et al., 2011). Furthermore, it questions the radiation of Ficus during the Tertiary after the break-up of Gondwana proposed by Zerega et al. (2005) and Cruaud et al. (2011). Since the Agaoninae females are short-lived and do not feed as adults, long distance dispersal, or emigration, is intimately subject to ecological factors, e.g., the fig wasps must accompany the fig host in their migration (Corner, 1958; Ramírez et al., 2011). Furthermore, the seeds of Ficus are small 0.5-5mm long (Corner, 1958), and short lived and the seedlings grow slowly. According to Zerega et al. (2005), long distance dispersal over water seems unlikely for Moraceae, owing to the large short-living seeds. Furthermore, long distant transoceanic dispersal for particular pollinating wasps and other sycophylous invertebrates must occur inside the syconia of living fig trees (Ramírez et al., 2011). It is suggested that for migration the suit of a living fig tree or trees and associated invertebrates have to travel together on a floating riparian, or on a coastal raft. Consequently, the author suggest that dispersion of Ficus seeds and its suits of sycophilous wasps and other associated organisms by wind, flying, or aquatic vertebrates displacing over long transoceanic distances, do not seem to have played a historical role in the intercontinental dispersion of the main groups of sycophillous wasps and other invertebrates (cf. Cruaud et al., 2011) for Sycophaginae dispersal. Due to the presence of two mandibular appendages and a membranous un-carinated gular bridge, as pleisiomorphies Agaoninae characters, the author suggests that Hexapus is the most ancestral clade of all extant fig pollinator genera; as well as, the sister clade of extant Tetrapus. This idea is reinforced by the molecular analysis of Cruaud et al. (2009), who placed Tetrapus n. sp. (=Hexapus sp., pers. obs.) as the most basal clade of 101 Agaoninae species representing 20 world-wide pollinating genera. The author suggests that Hexapus may represent the supposed South America extinct stem agaonine lineage proposed by LopezVaamonde et al. (2009). However, Cruad et al. (2012), concluded that neither their molecular study, nor previous ones, have a strong basis for inferring which agaonid group is sister to all other agaonids.

\section{ACKNOWLEDGMENTS}

I thank Paul E. Hanson, Julián MongeNájera and William Eberhard, University of Costa Rica, for reading the manuscript and suggesting various changes; Gilbert FuentesGonzález and the Organization for Tropical Studies for their assistance with literature and editing work; to Enrique Peñalver, Division of Invertebrate Zoology, American Museum of Natural History, for permission to use of some of the illustrations, and to Ana Cecilia Jinesta for the illustrations.

\section{RESUMEN}

Un fósil viviente de avispas de los higos (Hymenoptera, Agaoninae) que se desarrollan en especies de higos (Moraceae) existentes en el Neotrópico. Se ha asumido que las hembras de las avispas Tetrapus (Agaonidae s.s.), las polinizadoras de los higos de la sección Pharmacosycea del Nuevo Mundo, se caracterizan principalmente por la presencia de un solo apéndice mandibular, que es el clado más ancestral de los Agaonidae s.s. existentes y los machos son tetrápodos. El principal objetivo de este trabajo fue estudiar algunos morfotipos de avispas Tetrapus, cuyas hembras poseen dos apéndices mandibulares y los machos tres pares de patas funcionales (hexápodos); su asociación con sus higos hospederos y la posición filogenética en la familia Agaonidae. Cuestiono cuál grupo de avispas polinizadoras de los higos, constituye el grupo hermano de otras avispas polinizadoras de los higos (Agaonidae). Informo sobre un grupo de avispas (Tetrapus: Agaoninae) existentes, provisionalmente asignado a Hexapus subg. nov. en preparación. Morfológica, ecológica, geográfica e históricamente, Hexapus parece ser el clado ancestral de los polinizadores de higos Agaoninae existentes. Los morfotipos de Hexapus se desarrollan en especies de higos 
de la subsección Petenenses (sección Pharmacosycea). Las hembras de Tetrapus existentes tienen únicamente un apéndice mandibular y los machos tienen uno o dos lóbulos cortos, en lugar de las patas medias y por lo tanto no son funcionales (tetrápodos). Las hembras de Hexapus tienen dos apéndices mandibulares libres y los machos tienen patas medias funcionales con cinco segmentos (hexápodos). Molecularmente, Hexapus parece ser el clado ancestral de los Agaoninae existentes; por ejemplo, una especie de Tetrapus de Ficus crassivenosa fue colocado por otros autores como el clado ancestral de 101 especies de avispas que representan 19 géneros de Agaoninae mundiales, incluidas cuatro especies de Tetrapus. En Tetrapus sp. de Ficus crassivenosa, la hembra tiene dos apéndices mandibulares y el macho es hexápodo. Las hembras de T. apopnus y T. delclosi, descritas del Mioceno Temprano (Burdigaliense), conservadas en ámbar de la República Dominicana, también tienen dos apéndices mandibulares y la morfología general de Hexapus existente. El autor sugiere que Hexapus representa un fósil viviente y es un clado hermano de Tetrapus s.s. La presencia de Hexapus y Tetrapus actuales, y sus higos hospederos, especialmente en Suramérica, sugieren que tienen un origen en la Gondwana meridional del Cretácico. La presencia de Hexapus y Tetrapus en el Nuevo Mundo, no parece apoyar una conexión migratoria a través del Pacífico con América tropical, para los higos de la sección Pharmacosycea (los hospederos de Tetrapus y Hexapus), una amplia dispersión transoceánica, altos niveles de extinción básica de Tetrapus y conexiones terrestres a través del Atlántico, propuesto por otros autores. Sin embargo, últimamente se ha aceptado que los higos y sus polinizadores se originaron simultáneamente en Eurasia, durante el Terciario Primario y se diseminaron hacia el sur. La mayoría de estudios morfológicos y moleculares de biólogos de los Agaoninae y Ficus, no incluyeron morfotipos de Hexapus, o sus especies hospederas de Ficus y aceptadaron que Tetrapus es el clado más ancestral de las avispas polinizadoras de los higos existentes.

Palabras clave: Chalcidoidea, Agaoninae, Tetrapus, Hexapus, sección Pharmacosycea, fósil viviente.

\section{REFERENCES}

Azuma, H., Harrison, R. D., Nakamura, K., \& Su, Z. H. (2010). Molecular phylogenies of figs and figpollinating wasps in the Ryukyu and Bonin (Ogasawara) islands, Japan. Genes and Genetic Systems, 85, 177-192.

Berg, C. C. (1989). Clasification and distribution of Ficus. Experientia, 45, 605-611.

Berg, C. C. (2006). The subdivision of Ficus subgenus Pharmacocycea section Pharmacosycea (Moraceae). Blumea, 51, 147-151.
Berg, C. C. (2009). Flora of Ecuador No 85, 27C. In G. Harling, C., Persson, C. (Eds.), Moraceae (Ficus). Göteborg: University of Gothenburg.

Berg, C. C. \& Corner, E. J. H. (2005). Flora Malesiana (Moraceae-Ficus). Vol. 17, Part 2.

Bouček, Z. (1988). Australasian Chalcidoidea (Hymenoptera): A biosystematic revision of genera of fourteen families, with a reclassification of species. Wallingford, UK: CAB International.

Bouček, Z. (1993). The genera of chalcidoid wasps from Ficus fruit in the New World. Journal of Natural History, 27, 173-217.

Burger, W. (1977). Flora costaricensis. Family 52. Moraceae. Fieldiana. Botany, 40, 84-185.

Chen, C. H., \& Chou, L. Y. (1997). The Blastophagini of Taiwan (Hymenoptera: Agaonidae: Agaoninae). Journal of the Taiwan Museum, 50, 113-154.

Compton, S. G., Ball, A. D., Collinson, M. E., Hayes, P., Rasnitsyn, A. P., \& Ross, A. J. (2010). Ancient fig wasps indicate at least $34 \mathrm{Myr}$ of stasis in their mutualism with fig trees. Biology Letters, $16,838-842$.

Corner, E. J. H. (1958). An introduction to the distribution of Ficus. Reinwardtia, 4, 325-355.

Corner, E. J. H. (1960). Taxonomic notes on Ficus Linn., Asia and Australasia. XI. Subgenus Pharmacosycea Miq. The Gardens' Bulletin Singapore, 17, 368-485.

Corner, E. J. H. (1967). Ficus in the Solomon Islands and its bearing on the post-Jurassic history of Melanesia. Philosophical Transactions of the Royal Society B, 253, 23-159.

Cook, J. M., Bean, D., Power, S. A., \& Dixon, D. J. (2004). Evolution of a complex coevolved trait: active pollination in a genus of fig wasps. Journal of Evolutionary Biology, 17, 238-246.

Cruaud, A., Jabbour-Zahab, R., Genson, R., Cruaud, C., Couloux, A., Kjellberg, F., van Noort, S., \& Rasplus, J. Y. (2009). Laying the foundations for a new classification of Agaonidae (Hymenoptera: Chalcidoidea), a multilocus phylogenetic approach. Cladistics, $26,359-387$

Cruaud, A., Jabbour-Zahab, R., Genson, G., Couloxux, A., Yan-Qiong, P., Rong, Y. D., ... Rasplus, Y. R. (2011). Out of Australia and back again: the world-wide historical biogeography of non-pollinating fig wasps (Hymenoptera: Sycophaginae). Journal of Biogeography, 38, 209-225.

Cruaud, A., Rønsted, N., Chantarasuwan, B., Chou, L. S., Clement, W. L., Couloux, A., ... Savolainen, V. (2012). An extreme case of plant-insect 
codiversification: Figs and fig-pollinating wasps. Systematic Biology, 61, 1029-1047.

Datwyler, S. L., \& Weiblen, G. D. (2004). On the origin of the fig: Phylogenetic relationships of Moraceae from $N D H F$ sequences. American Journal of Botany, 91, 767-777.

Erasmus, J. C., van Noort, S., Jousselin, E., \& Greeff, J. M. (2007). Molecular phylogeny of fig wasps pollinators (Agaonidae, Hymenoptera) of Ficus section Galoglychia. Zoologica Scrypta, 36, 61-78.

Graham, M. V. de V. (1969). The Pteromalidae of North-Western Europe (Hymenoptera: Chalcidoidea). Bulletin of the British Museum (Natural History) (Entomology) Suppl., 16, 1-908.

Grandi, G. (1916). Contributo alla conoscenza degli Agaonini (Hymenoptera, Chalcididae) di Ceylon e dell' India. Bollettino del Laboratorio di Zoologia Generale e Agraria della R. Scuola Superiore d'Agricoltura, Portici, 11, 183-234.

Harrison, R. D. (2005). Figs and the diversity of tropical rainforest. BioScience, 55, 1053-1064.

Heraty, J. M., Burks, R. A., Cruaud, A., Gibson, G. A. P., Liljeblad, J., Munro, J., ... Yoder, M. (2013). A phylogenetic analysis of megadiverse Chalcidoidea (Hymenoptera). Cladistics, 29, 466-542.

Herre, E. A., Machado, C. A., Bermingham, E., Nason, J. D., Windsor, D. M., McCafferty, S. S., ... Bachma, K. (1996). Molecular phylogenies of figs and their pollinator wasps. Journal of Biogeography, 23, 521-530.

Iturralde-Vinent, M., \& MacPhee, R. (1996). Age and paleogeographic origin of Dominican amber. Science, $273,2750-2752$

Jiang, Z. F., Huang, D. W., Zhu, C. D., \& Zhen, W. Q. (2006). New insights into the phylogeny of fig pollinators using Bayesian analyses. Molecular Phylogenetics and Evolution, 38, 306-315.

Jousselin, E., Rasplus, J. Y., \& Kjellberg, F. (2003). Convergence and coevolution in a mutualism: Evidence from a molecular phylogeny of Ficus. Evolution, $57,1255-1269$.

Kjellberg, F., Jousselin, E., Bronstein, J. L., Patel, A., Yokoyama, J., \& Rasplus, J. Y. (2001). Pollination mode in fig wasps: the predictive power of correlated traits. Proceedings of the Royal Society B, $268,1113-1121$.

Lopez-Vaamonde, C., Dixon, D. J., Cook, J. M., \& Rasplus, J. Y. (2002). Revision of the Australian species of Pleistodontes (Hymenoptera: Agaonidae) fig-pollinating wasps and their host-plant associations. Zoological Journal of the Linnean Society, 136, 637-683.
Lopez-Vaamonde, C., Wikström, N., Kjer, K. M., Weiblen, G. D., Rasplus, J. Y., Machado, C. A., \& Cook, J. M. (2009). Molecular dating and biogeography of fig-pollinating wasps. Molecular Phylogenetics and Evolution, 52, 715-726.

Machado, C. A., Herre, E. A., McCafferty, S., \& Bermingham, E. (1996). Molecular phylogenies of fig pollinating and non-pollinating wasps and the implications for the origin and evolution of the fig-fig wasp mutualism. Journal of Biogeography, 23, 531-542.

Machado, C. A., Jousselin, E., Kjellberg, F., Compton, S. G., \& Herre, E. A. (2001). Phylogenetic relationships, historical biogeography and character evolution of fig-pollinating wasps. Proceedings of the Royal Society B, 268, 685-694.

Mayr, G. L. (1885). Feigeninsecten. Verhandlungen der Zoologisch-Botanischen Gesellschaft in Wien, $35,147-250$.

McKey, D. (1989). Population biology of figs: Applications for conservation. Experientia, 45, 661-673.

Munro, J. B., Heraty, J. M., Burks, R. A., Hawks, D., Mottem, J., Cruaud, A., Rasplus, J. Y., \& Jansta, P. (2011). A molecular phylogeny of the Chalcidoidea (Hymenoptera). PLoS ONE, 6(11): e27023.

Murray, M. G. (1985). Figs (Ficus spp.) and fig wasps (Chalcidoidea, Agaonidae): hypotheses for an ancient symbiosis. Biological Journal of the Linnean Society, $26,69-81$

Peñalver, E., Engel, M. S., \& Grimaldi, D. A. (2006). Fig wasps in Dominican amber (Hymenoptera: Agaonidae). American Museum Novitates, 3541, 1-15.

Ramírez, W. (1970). Taxonomic and biological studies of Neotropical fig wasps (Hymenoptera: Agaonidae). The University of Kansas Science Bulletin, 49, 1-44.

Ramírez, W. (1978). Evolution of mechanisms to carry pollen in Agaonidae (Hymenoptera: Chalcidoidea). Tijdschrift voor Entomologie, 121, 279-293.

Ramírez, W. (1989). Dispersal and colonization of Ficus in the New World. In P. R. Crane \& S. Blackmore (Eds.), Evolution, Systematics, and Fossil History of the Hamamelidae, 'Higher' Hamamelidae'(vol. 2, pp. 279-284). Oxford, UK: Clarendon Press.

Ramírez, W. (1991). Evolution of the mandibular appendage in fig wasps (Hymenoptera: Agaonidae). Revista de Biología Tropical, 39, 87-95.

Ramírez, W. (1994). Hybridization of Ficus religiosa with F. septica and F. aurea (Moraceae). Revista de Biología Tropical, 42, 339-342.

Ramírez, W. (2007). Pollination analogies between Orchidaceae, Ficus (Moraceae) and Asclepiadaceae. Lankesteriana, 7, 450-457. 
Ramírez, W., Gómez, J., Salazar, L., \& Aguilar, H. (2011). Ficus trigonata (Moraceae) and associated invertebrates organisms living in its syconia in Cocos Island. Costa Rica. Brenesia, 75-76, 16-22.

Ramírez, W., \& Malavasi, J. (1997). Fig wasps: mechanisms of pollen transfer in Malvanthera and Pharmacosycea figs (Moraceae). Revista de Biología Tropical, 45, 1635-1640.

Ramírez, W., Monge, J., \& Chavarría, J. B. (2009). Sex ratio in two species of Pegoscapus wasps (Hymenoptera: Agaonidae) that develop in figs: can wasps do mathematics, or play sex ratio games. Revista de Biología Tropical, 57, 605-621.

Ramírez, W., \& Salazar, L. (2015). Parasitodiplogaster citrinema is an internal necrophagous species of the pollinating fig wasp Pegoscapus tonduzi. Nematology, 17, 733-738.

Rasplus, J. Y., Kerdelhué, C., Le Clainche, I., \& Mondor, G. (1998). Molecular phylogeny of fig wasps Agaonidae are not monophyletic. Comptes Rendus de l'Academie des Sciences. Series III, Sciences de la Vie, 321, 517-527.

Rønsted, N., Weiblen, G., Clement, W. L., Zerega, N. J. C., \& Savolainen, P. (2008). Reconstructing the phylogeny of figs (Ficus, Moraceae) to reveal the history of the fig pollination mutualism. Symbiosis, 45, 45-55.

Rønsted, N., Weiblen, G. D., Cook, J. M., Salamin, N., Machado, C. A., \& Savolainen, V. (2005). 60 million years of co-divergence in the fig-wasp symbiosis. Proceedings of the Royal Society B, 272, 2593-2599.

Saunders, S. S. (1883). Descriptions of three new genera and species of fig insects allied to Blastophaga from Calcutta, Australia, and Madagascar; with notes on their parasites and of the affinities of the respective races. Transactions of the Royal Entomological Society of London, 31, 1-28.
Segar, S. T., Lopez-Vaamonde, C., Rasplus, J. Y., \& Cook, J. M. (2012). The global phylogeny of the subfamily Sycoryctinae (Pteromalidae): parasites of an obligate mutualism. Molecular Phylogenetics and Evolution, $65,116-125$.

Wang, G., Chen, J., Li, Z. B., Zhang, F. P., \& Yang, D. R. (2014). Has pollination mode shaped the evolution of Ficus pollen? PLoS ONE, 9(1), E86231. doi 10.1371/ journal.pone.0086231

Weiblen, G. D. (2000). Phylogenetic relationships of functionally dioecious Ficus (Moraceae) based on ribosomal DNA sequences and morphology. American Journal of Botany, 87, 1342-1357.

Weiblen, G. D. (2002). How to be a fig wasp. Annual Review of Entomology, 47, 299-330.

Wiebes, J. T (1977). Zoologische Mededelingen Uitgegeven Door Het. Indo-Malayan and Papuan fig Wasps (Hymenoptera, Chalcidoidea) 7. Agaonidae, mainly caught at light, 52, 136-159.

Wiebes, J. T (1979). The fig wasps genus Dolichoris Hill (Hymenoptera Chalcidoidea, Agaonidae). Proceedings. Koninklijke Nederlandse Akademie van Wetenschappen, Amsterdam (C), 82, 181-196.

Wiebes, J. T. (1982). The phylogeny of the Agaonidae (Hymenoptera, Chalcidoidea). Netherlands Journal of Zoology, 32, 395-411.

Wiebes, J. T. (1995). The New World Agaoninae (pollinators of figs) (Vol. 94, pp. 1-60). Amsterdam, North-Holland.

Yokoyama, J. (2003). Cospeciation of figs and fig-wasps: a case study of endemic species pairs in the Ogasawara Islands. Population Ecology, 45, 249-256.

Zerega, N. J., Clement, W. L., Datwyler, S. L., \& Weiblen, G. D. (2005). Biogeography and divergence times in the mulberry family (Moraceae). Molecular Phylogenetics and Evolution, 37, 402-406. 
